\title{
Reducing the Public Speaking Anxiety of ESL College Students Through Popsispeak
}

\author{
MARLON S. PONTILLAS \\ Camarines Sur Polytechnic Colleges \\ Nabua, Camarines Sur, Philippines \\ arlpontillas@yahoo.com
}

\begin{abstract}
It is evident that even students had already English subjects in the primary and secondary years, some of them are afraid to use the English language in the classroom in the tertiary level. They find difficulty in expressing themselves using the said language because of several factors. This study focuses on helping the students face their fear in public speaking, which interferes their oral communication skills. The teacher-researcher introduced an intervention called Popsispeak. This study utilized a one-shot case study. A total of 28 students of Camarines Sur Polytechnic Colleges who were enrolled in the class of the teacher-researcher for the A.Y. 2017-2018 2nd semester served as the respondents of the study. T-test for Dependent Samples was used to determine the significant difference between the pre-test and post-test results of the students' Personal Report of Public Speaking Anxiety (PRPSA) devised by McCroskey. The same statistical tool was also used in determining the level of oral communication skills of the students before and after the intervention. Pearson's Correlation was used in determining the relationship between public speaking anxiety and oral communication skills. Also, thematic analysis was utilized in grouping the responses of the students regarding their experiences in the intervention activity. It was found out that Popsispeak is an effective intervention in helping students elevate their oral communication skills and reduce their public speaking anxiety.
\end{abstract}

Keywords: Oral Communication; Public Speaking Anxiety; Popsispeak, ESL; Philippines

\section{INTRODUCTION}

In a competitive world in today's time, 21 st-century skills should be possessed by the students to emerge triumphant in the information age (Thoughtful Learning, 2016). 21st-century skills are holistic skills in all aspects - knowledge, skills, and values that are believed to be crucial in the workplace. Hence, the learning institution should prepare the students to cope with the demands outside the portals of the academe (Hidden Curriculum, 2014).

Communicating is one of the 4Cs in Learning Skills under 21st Century Skills. It is noted in the National Institute of Education in Singapore that Communication skills are one of the attributes of the 21st Century Teaching Professional. The English language has been considered as a skill since it is the Universal language that we are using. Candidates with strong linguistic skills have a strong edge as far as employment is concerned. People with a strong English language facility can express themselves smoothly and clearly. That is why, as early as primary years, teachers train their students to practice their oral communication skills through several classroom activities.

Teachers utilize various assessment methods to gauge students' learning. Some of them use recitation as a form of assessment. They ask a specific question, and students should answer the question in a short span of time. Some students fail because even they know the answers, they are hesitant to speak because of public speaking anxiety.

An online article stated that a social fear in public speaking is called glossophobia, where an estimated $75 \%$ of the world population faces this struggle which means that 238 million people feel nervous when talking to others. The article also stated that in one of their studies, fear in public speaking might be linked to the level of person's education, the more a person is educated, the lesser the fear in public speaking is experienced. (Lake, 2015). 
Public speaking is defined in different contexts. Generally, it is a type of interpersonal communication that deals with speech delivery either in formal or informal events with the purpose of informing, persuading, or entertaining a large group of audience. This type of communication is one of the most challenging tasks a person faces because of several factors: Language Proficiency, Problem in Organization of Speech content, and Lack Public Speaking Skill. In this study, this will just be delimited in the classroom setup wherein the student who will serve as the speaker will only be facing his/her teacher and classmates.

Anxiety in speaking is not only attributed to the use of the foreign language but the fact that students are facing a crowd (Young, 1990). It is also manifested during an oral presentation, speech delivery, and even in their own learning process (Arafah et al., 2017). People with speaking anxiety can be seen through their gestures and actions. Some of them experienced trembling, uneasiness, stress, sweating, and apprehension (University of Wisconsin, 2012).

This kind of anxiety is also manifested to learners whose second language is English. Nazir, Bashir, and Raja (2014) found out through an anxiety scale that most of the Pakistani learners have a high level of communication apprehension, which hinders them from speaking the English language in the classroom. Another study revealed that Pakistani students have this high apprehension in communication is because of their teachers who politicize students based on their ethnicity and social status (Dhar \& Khan, 2014). Even Chinese students who are already at the tertiary level experienced high communication apprehension, especially when they are tasked to speak English in front of the class without preparation. They find difficulty in expressing themselves in the said language since they are used to their first language (Mak, 2011).

In the Philippines, although English is already a second language, where English has been the medium of instruction from elementary to post-graduate levels, Filipinos still have moderate to high speaking communication anxiety. Del Villar (2010) posited that several factors affect this kind of anxiety, such as prior unpleasant experience, rejection, foundation in education, verbal fluency, and others. She believed, however, that the anxiety experienced by Filipino learners can be reduced with the proper intervention and guidance of educators, especially the language teachers.

In Camarines Sur Polytechnic Colleges (CSPC), one of the tertiary schools in the Philippines, a lot of students face the anxiety as mentioned above. During the first semester of the teaching of the teacher-researcher, he handled Speech and Oral Communication to Engineering students. He noticed that the majority of his students experienced fear in speaking in front of the class during recitations and oral communication drills. This led to low scores during the assessment. Before the semester ends, the teacher-researcher conducted a small group discussion, and he found out that these students are not exposed to public speaking activities in their previous years and felt inferior in the use of English language.

The reason for doing such is that the teacher-researcher would like to design an intervention in his class to address the learners' problems in speaking anxiety tailored fit to the experience of the students. With appropriate teaching strategies to provide aid to language learners, language learning will be smooth and be delivered successfully in English as a Second Language (ESL) classroom (Suwanarak, 2019). Indeed, teachers should be aware of the learning style of the students to decide the most appropriate strategy needed to address the difficulties of their learners (Philip, Hua, Jandar, 2019).

Because of this, the teacher-researcher is thrilled to introduce an Outcomes Based Teaching and Learning Strategy that he conceptualized for the improvement of students' public speaking skills and to reduce their public speaking anxiety. This is called Popsispeak. This applies not only to English classes but across different subject areas. Through this action research, the teacher-researcher will find out if the said Outcomes Based Teaching and 
Learning Strategy is an effective intervention in addressing the communicative skills of the students.

\section{THE FRAMEWORK OF THE STUDY}

Many scholars in Communication have investigated several details about the psychological and physiological features of public speaking anxiety. It is often viewed toward developing interventions that will minimize the negative effects of anxiety for public speakers. However, little attention has been given to another corollary phenomenon that may hinder the communication effectiveness of individuals while making public presentations - speakers' depression. (Witt, Roberts, \& Behnke, 2000) This anxiety affects the behavior of a person when they are in front of the audience before during and after the speech delivery and, also, the teacher used an intervention to reduce the anxiety of students in speech delivery. The research used the Behavioral Learning Theory and Classical Conditioning Theory.

Behavioral Learning Theory is defined as the relatively permanent change brought as a result of experience and practice. It recognizes that learning is an internal event, and it is known as learning until it is displayed by overt behavior. It is a learning theory associated with the behavioral view and focuses on the behavioral approach on how the environment affects overt behavior. This theory is interested in feedback that connects directly to overt behavior. (Huitt \& Hummel, 1999). Since the intervention includes a motivational letter to the learners, the learners will be able to identify their strengths and weaknesses in their speaking performance. Hence, they can further assess and address their points for improvement to reduce their speaking anxiety.

Ivan Pavlov, a Russian Scientist, was the proponent of Classical Conditioning Theory. This involves learning a new behavior via the process of association. In simple terms, two stimuli are linked together to produce a new learned response in a person or animal. Everything from speech to emotional responses was simply patterns of stimulus and response. In this study, the stimuli are the motivational prompts and reflection notes of the learners, which will find out whether the two could bring significant change to the performance of the learners.

\section{PURPOSE OF THE RESEARCH}

The purpose of this action research is to find out the effectiveness of Popsispeak in reducing the public speaking anxiety of the students in Camarines Sur Polytechnic Colleges. Specifically, the study attempted to answer the following questions:

1. What is the speaking anxiety level of the students before and after the intervention?

2. What is the oral communication skills level of the students before and after the intervention?

3. How significant is the improvement before and after the intervention?

4. How significant is the relationship between speaking anxiety and oral communication skills of the students?

5. What are the insights gained by the respondents every after Popsispeak activity?

6. What output can be generated based on the results of the study?

\section{HYPOTHESES}

1. There is a significant difference before and after the intervention.

2. There is a significant relationship between public speaking anxiety and oral communication skills of the students. 


\section{METHODOLOGY}

The main focus of this study was to reduce the public speaking anxiety of students in Camarines Sur Polytechnic Colleges through popsispeak. This study utilized a "one-shot case study" research design. In this kind of design, subjects are presented with an intervention for a whole semester and the objective is to know if the intervention had an impact or not.

\section{STATISTICAL SAMPLING}

A complete enumeration of 28 BS Midwifery second-year students of Camarines Sur Polytechnic Colleges enrolled for the 2nd semester A.Y. 2017-2018. There was no statistical sampling used. To get the significant difference between the effectiveness of the intervention, t-test for dependent samples was used. Also, to know the relationship between the levels of public speaking anxiety and oral communication skills, Pearson Moment of Correlation was utilized.

\section{DESCRIPTION OF INSTRUMENT/DATA GATHERING FOCUS}

A standardized test of Personal Report of Public Speaking Anxiety (PRPSA) was used in this study. This is devised by James McCroskey. There are 34 statements included in the test to know the level of their public speaking anxiety. The said test was administered before and after the implementation of the said intervention. To determine the Oral Communication Skills level of the respondents, an Impromptu Speech rubric was used by the Instructor. This was administered before and after the intervention. The rubric was validated by the Dean of College of Education, Arts and Sciences and a language expert. Lastly, to gather and interpret the insights of the respondents every after their turn in Popsispeak, a thematic approach was utilized by the teacher-researcher.

\section{TRIANGULATION METHOD}

To have an in-depth discussion of the study, the teacher-researcher did not only rely on the perceived public speaking anxiety of the students. He utilized two more methods to validate the results. He crafted a teacher-made rubric to evaluate the oral communication skills level of the students. Also, he analysed the responses of the students' learning journals through a thematic approach.

\section{PRE-INTERVENTION}

The teacher-researcher sought permission to the dean of the Health Care Technology department for the approval of the conduct of the study. After the dean's approval, he integrated the mechanics of the intervention in the class syllabus to formalize the process. On the first day of class, the teacher-researcher explained the purpose of the study to the students. He likewise sought permission to the students who served as the subject of the study. $100 \%$ of the students agreed to undergo the process.

\section{INTERVENTION}

Small pieces of paper with a variety of topics printed on it were pasted on recycled Popsicle sticks that fit its size. The teacher-researcher identified the topics. Every meeting, before the start of the lesson proper, there were 3-5 speakers of the day. In the form of lottery, students picked their topic and were given a maximum of 1.5-minute delivery. After the speech delivery, students were given a motivational letter by the teacher-researcher and the ways to improve 
more of his/her speaking skills were also included. On the next meeting, a reflective journal was submitted to the teacher-researcher regarding their assessment of their performance for the day. Their performances were not graded nor part of the computation of the subject. However, the teacher-researcher gave incentives by adding extra points in the class participation to those students who have shown improvement.

\section{POST-INTERVENTION}

Before the semester ends, students successfully had three rounds of Popsispeak. The teacherresearcher conducted a SWOT analysis through a small group discussion to the students. Students raised their recommendations for the improvement of the said intervention.

\section{RESULTS}

All the data gathered were subsequently organised, analysed, and interpreted to answer the questions posed in the study.

\section{PERCEIVED SPEAKING ANXIETY LEVEL OF THE STUDENTS BEFORE THE CONDUCT OF POPSISPEAK}

Table 1 shows the before the intervention results of the Personal Report of Public Speaking Anxiety by McCroskey. The teacher-researcher conducted the test on the first day of the classes. 28 students or $100 \%$ of the class were the subjects of the study. The test is composed of 34 items wherein students can state if they believe or not on the statements stipulated on the questionnaire.

TABLE 1. PRPSA Results (Before the Intervention)

\begin{tabular}{ccc}
\hline Level of Anxiety & No. of Students & Percentage \\
\hline $\begin{array}{c}\text { Low } \\
<98\end{array}$ & 2 & 7.14 \\
$\begin{array}{c}\text { Moderate } \\
98-131\end{array}$ & 16 & 57.14 \\
High & & \\
$>131$ & 10 & 35.71 \\
TOTAL & 28 & 100.00 \\
\hline
\end{tabular}

The results imply that the majority of the students have moderate public speaking anxiety before the teacher-researcher introduces the intervention.

\footnotetext{
"I am so nervous when my name was called to speak in front of class. My hands were shaking, my knees were trembling. I just want to disappear by that time. I must admit, I am not confident as compare with my other classmates, "Student A said.

"I could still remember when my fourth grade teacher embarrassed me inside the class because I cannot speak English well. I was traumatized. From that day on, I had a fear speaking in front of the class," Student $B$ added.
}

Jangir and Govinda (2017) posited that anxiety becomes evident to students who feel nervousness and consciousness speaking in front of the class because of several factors. Also, other symptoms which manifest that students feel anxiety are palpitations, muscle tension, sweating, confusion, and others. (North \& Rives, 2001). Another factor that can contribute to the anxiety of the students is the uncomfortable use of the foreign language, which can interfere them during classroom activities (Yalçın \& İnceçay, 2014). 


\section{PERCEIVED SPEAKING ANXIETY LEVEL OF THE STUDENTS AFTER THE CONDUCT OF POPSISPEAK}

Table 2 shows after the intervention results of the Personal Report of Public Speaking Anxiety by McCroskey. The teacher-researcher conducted the said test before the end of the semester. The same number of students in the pre-test was utilized in this test. The test is the same number of items and content of the pre-test questionnaire

TABLE 2. PRPSA Results (After the Intervention)

\begin{tabular}{ccc}
\hline Level of Anxiety & No. of Students & Percentage \\
\hline $\begin{array}{c}\text { Low } \\
<98\end{array}$ & 13 & 46.43 \\
$\begin{array}{c}\text { Moderate } \\
98-131 \\
\text { High }\end{array}$ & 13 & 46.43 \\
$>131$ & 2 & 7.14 \\
TOTAL & & \\
\hline
\end{tabular}

The results imply that there were only two students or $7.14 \%$ of the population perceived that they still have a high anxiety level. During the pre-test, ten students or $35.71 \%$ of the population reported that they experienced a high anxiety level in public speaking. It can be inferred that after the intervention was conducted for the whole semester, a significant change transpired.

\footnotetext{
"From high level of anxiety, I am happy that my speaking anxiety was reduced. I thought I cannot make it, but there's nothing impossible if you will practice and believe to yourself," Student A stressed.

"I thought my high level of anxiety cannot be cured anymore because of my horrible past experience during elementary days. But through popsispeak and because of the continuous support by my instructor, I made it! Thank God!'” Student B pointed out.
}

A skills-based program in Japan was conducted to reduce the public speaking anxiety of college students and was found effective (Pribyl, Keaten \& Sakamoto, 2001). Also, a pilot study using Emotional Freedom Techniques was conducted by experts and found out that the said intervention was found relaxing and helpful in combating the anxiety level in public speaking of the participants of the study (Boath, Good, Tsaroucha, Stewart, Pitch, \& Boughey, 2017). In the field of healthcare, it was divulged that the awareness of the words you will utter, preparation of the presentation, and normal breathing would help nurses reduce their public speaking anxiety (Overcoming the Jitters, 2002).

\section{ORAL COMMUNICATION SKILLS LEVEL OF THE STUDENTS BEFORE THE CONDUCT OF POPSISPEAK}

Table 3 shows the before the intervention results using the teacher-made rubric that gauged the oral communication skills level of the students. The students were graded according to the organization, delivery, and content of their speeches. The teacher-researcher conducted the said test before application of the intervention. 28 students or $100 \%$ of the class were the subjects of the study.

TABLE 3. Level of Oral Communication Skills (Before the Intervention)

\begin{tabular}{ccc}
\hline Level of Skills & No. of Students & Percentage \\
\hline $\begin{array}{c}\text { Advanced } \\
\text { Scores (25-30) } \\
\text { Proficient } \\
\text { Scores (19-24) }\end{array}$ & 0 & 0.00 \\
Approaching Proficiency \\
$\begin{array}{c}\text { Scores (13-18) } \\
\text { Developing }\end{array}$ & 6 & 21.43 \\
\hline
\end{tabular}




\begin{tabular}{ccc}
\hline Scores (7-12) & & \\
Beginning & 7 & 25.00 \\
Scores (0-6) & 28 & 100.00 \\
Total & & \\
\hline
\end{tabular}

The data imply that majority, eight students, or $28.57 \%$ of the total population, are classified to developing level which is the second lowest level among the five indicators. This means that before the intervention is applied, the majority of them are not well-versed regarding oral communication skills and need drills and exercises to develop such skills.

\begin{abstract}
"When we were in elementary and high school, I was not given exposure to practice my oral communication skills. I observed that majority of our language teachers focused on reading and writing skills. I know, I need to learn and practice more to improve my oral comm. skills, "Student C confessed. "My confidence really affects my communication skills. I feel that when I commit errors in grammar, people will judge and mock me. I should work out with my fillers. These are inevitable every time I speak. I cannot control it. These are my mannerisms, " Student D posited.
\end{abstract}

In the globalized world that we live in, professional competition is widely evident. To survive in the hangar of the corporate world, one should have strong oral communication skill. Simon (2013) revealed in his study that a person should be well-versed both in his mother tongue and at least one international language. A bachelor's program in Romania helps to interweave languages such as English, German, or French. The said program highlights Writing, Oral, and Grammar skills of the students. In an essay article, Sharma (2017) posited that exceptional oral communication skills would be an advantage for the students in landing a good career in the future. Several tips were discussed in his article to develop the said skills. On the other hand, poor communication skills are attributed to the lack of students' exposure to the language, lack of activities and instructional materials that would enhance the learners' skills, and other external factors (Nkome, 2015).

\title{
ORAL COMMUNICATION SKILLS LEVEL OF THE STUDENTS AFTER THE CONDUCT OF POPSISPEAK
}

Table 4 shows after the intervention results using the teacher-made rubric that gauged the oral communication skills level of the students. Same, the students were graded according to the organization, delivery, and content of their speeches. The teacher-researcher conducted the said test after the application of the intervention.

TABLE 4. Level of Oral Communication Skills (After the Intervention)

\begin{tabular}{|c|c|c|}
\hline Level of Skills & No. of Students & Percentage \\
\hline Advanced & 0 & 0.00 \\
\hline Scores $(25-30)$ & & \\
\hline Proficient & 10 & 35.71 \\
\hline Scores (19-24) & & \\
\hline $\begin{array}{l}\text { Approaching Proficiency } \\
\text { Scores (13-18) }\end{array}$ & 9 & 32.14 \\
\hline Developing & 8 & 28.57 \\
\hline Scores $(7-12)$ & & \\
\hline $\begin{array}{l}\text { Beginning } \\
\text { Scores }(0-6)\end{array}$ & 1 & 3.57 \\
\hline Total & 28 & 100.00 \\
\hline
\end{tabular}

The results imply that after the intervention, the majority of the students rose to the proficient level, which is the second highest level among the five parameters. It can be deduced that Popsispeak helped the students to elevate their oral communication skills. 
"Aside from combating my fear, through popsispeak, I know, my oral communication skills improved in a way. Although I know I still need more drills like this, this has just been a very good start," Student $C$ said.

"From a very low score in the start of the semester, I am so surprised that my level improved a lot. I also noticed that the number of fillers I uttered reduced and my mannerisms were not as evident as before," Student D uttered.

Graduate studies students were now successful in their chosen careers because of their strong oral communication skills. Varied classroom learning activities like individual/group presentations, significantly helped them acquire the said skills (Jackson 2014). Another teaching strategy that helped students improve their oral communication skills is think-pairshare (TPS). This strategy stimulated the creativity and motivation of the students to work in groups. Thus, aside from their communication skills, their collaborative skills were also developed (Raba, 2017). Lastly, the attitude of the learners in learning a language should not be ignored to help improve their communication skills. Strategies in speaking in learning institutions should also be given emphasis (Rastegar \& Gohari, 2016).

\section{SIGNIFICANT DIFFERENCE IN THE PUBLIC SPEAKING ANXIETY LEVEL OF THE STUDENTS BEFORE AND AFTER THE POPSISPEAK ACTIVITY}

Table 5 shows the significant difference on the public speaking anxiety level of the students. Findings show that the p-value of .000 is less than 0.05 . Also, the t-computed value of -6.253 is greater than the t-critical value of 2.052 at $5 \%$ and 2.771 at $1 \%$ levels of significance. Therefore, the null hypothesis is rejected. This means that there is a significant difference in the public speaking anxiety level of the students before and after the intervention.

TABLE 5. Significant Difference in the Public Speaking Anxiety Level

\begin{tabular}{|c|c|c|}
\hline & Before the Intervention & After the Intervention \\
\hline Mean & 125.43 & 99.07 \\
\hline Standard Deviation & 18.40 & 23.89 \\
\hline Number of Samples & \multicolumn{2}{|c|}{28} \\
\hline t-value & \multicolumn{2}{|c|}{-6.253} \\
\hline p-value & \multicolumn{2}{|c|}{.000} \\
\hline Interpretation & \multicolumn{2}{|c|}{ Significant } \\
\hline Critical Value & \multicolumn{2}{|c|}{2.052 at $5 \%$ and 2.771 at $1 \%$ Levels of Significance } \\
\hline
\end{tabular}

The results imply that Popsispeak is an effective intervention in reducing the public speaking anxiety level of the students. Because of the students' exposure to this kind of activity, they are motivated to excel in their next turns. Hence, their anxiety levels have lessened. This is supported by the theory used in the study, which is the Behavioral Learning Theory. Through experience and constant practice, learning takes place in the environment (Huitt \& Hummel, 1999). Exposures to different activities such as diction and speech exercises help the learners to conquer their fear of speaking in front of the crowd (Carnegie, 2009). Also, aside from exposing to different activities, technology can also aid learners in conquering their public speaking anxiety. Virtual Reality Therapy (VRT) was found to be effective in reducing the anxiety of the students (Harris, Kemerling, \& North 2004).

\section{SIGNIFICANT DIFFERENCE IN THE ORAL COMMUNICATION SKILLS LEVEL OF THE STUDENTS BEFORE AND AFTER THE POPSISPEAK ACTIVITY}

Table 6 shows the significant difference in the oral communication skills level of the students. Findings show that the p-values of $.000, .000, .003$, and .000 in organization, content, delivery, and overall results of communication skills are less than 0.05 , respectively. Also, the $t-$ computed values of 5.133, 5.875, 3.289, 5.774 are greater than the t-critical value of 2.052 at 
$5 \%$ and 2.771 at $1 \%$ levels of significance, respectively. Therefore, the null hypothesis is rejected. This means that there is a significant difference on the oral communication skills level of the students before and after the intervention.

TABLE 6. Significant Difference in the Oral Communication Skills Level

\begin{tabular}{|c|c|c|c|c|c|c|c|c|}
\hline & \multicolumn{2}{|c|}{ Organization } & \multicolumn{2}{|c|}{ Content } & \multicolumn{2}{|c|}{ Delivery } & \multicolumn{2}{|c|}{ Overall } \\
\hline & Before & After & Before & After & Before & After & Before & After \\
\hline Mean & 4 & 5.32 & 3.86 & 5.32 & 3.96 & 5.00 & 11.57 & 15.64 \\
\hline SD & 2.55 & 1.91 & 2.48 & 1.74 & 2.74 & 2.14 & 7.46 & 5.66 \\
\hline $\mathrm{N}$ & \multicolumn{8}{|c|}{28} \\
\hline t-value & \multirow{2}{*}{\multicolumn{2}{|c|}{$\begin{array}{c}5.133 \\
.000\end{array}$}} & \multirow{2}{*}{\multicolumn{2}{|c|}{5.875}} & \multicolumn{2}{|c|}{3.289} & \multicolumn{2}{|c|}{5.774} \\
\hline p-value & & & & & & & \multirow{3}{*}{\multicolumn{2}{|c|}{$\begin{array}{c}.000 \\
\text { Significant }\end{array}$}} \\
\hline Interpretation & \multirow{2}{*}{\multicolumn{2}{|c|}{ Significant }} & \multicolumn{2}{|c|}{ Significant } & \multicolumn{2}{|c|}{ Significant } & & \\
\hline Critical Value & & & 2.052 at 50 & 2.771 & Levels & nnifican & & \\
\hline
\end{tabular}

The data imply that Popsispeak helped improve the oral communication skills of the students. It was noted that their communication skills are affected by their public speaking anxiety. Since it was proven that their anxiety level lessened, their oral communication skills had also improved. The motivation that the teacher-researcher imparted to the students helped in creating a successful learning process. This is supported by one of the theories used in the study- the classical conditioning theory. The stimulus is the learner's motivation to enhance his skills. On the other hand, the response is the shown improvement of the learner's skills after the intervention activity. Exposure of students to various activities such as oral reports and oral presented instead of the paper and pencil kind of assessment helped the students improve their language skills and even professional behaviors (Reitmeier, Svendsen, \& Vrchota, 2006). In addition, metacognitive training is also an effective intervention to improve the oral proficiency of the students (Nakatani 2005).

\section{SIGNIFICANT RELATIONSHIP BETWEEN PUBLIC SPEAKING ANXIETY AND ORAL COMMUNICATION SKILLS}

Table 7 shows the relationship between public speaking anxiety and oral communication skills of the students. Findings show that the p-values of $.118, .088, .064$, and .080 in organization vs. anxiety, content vs. anxiety, delivery vs. anxiety, and overall communication vs. anxiety are less than .05 , respectively. Therefore, the null hypothesis is accepted. This means that there is no significant relationship between public speaking anxiety and oral communication skills of the students.

TABLE 7. Relationship Between Anxiety Levels and Communication Levels

\begin{tabular}{|c|c|c|c|c|}
\hline & Organization & Content Anxiety & Delivery & Communication \\
\hline r-value & -.302 & -.329 & -.354 & -.337 \\
\hline p-value & .118 & .088 & .064 & .080 \\
\hline Interpretation & Not Significant & Not Significant & Not Significant & Not Significant \\
\hline Significance & & & & \\
\hline Level & & Significant if the & -value is less than .05 & \\
\hline
\end{tabular}

The results imply that public speaking anxiety and oral communication skills are not related to each other. This is supported by a study that found out that the anxiety level is not correlated with the communication skills level of the students. This means that even the students have low public speaking anxiety, this does not mean that they are good public speakers (Kamridah, Yassi, Arafah, \& Imran, 2015). However, for the students to develop their speaking abilities, they have to address first their public speaking anxiety. Students who have this anxiety can perform well in the class if they can find strategies to combat their fears (Raja, 2017). 


\section{INSIGHTS GAINED BY THE STUDENTS EVERY AFTER THE POPSISPEAK ACTIVITY}

Table 8 shows the responses of the respondents every after the activity. The responses were written in the journal wherein their reflection on their performance was self-assessed. For the whole semester, there is a total of three rounds where the students completely had their complete turns. Through thematic analysis, the responses were grouped according to their similarities.

TABLE 8. Generated Themes on the Students' Responses

\begin{tabular}{|c|c|c|c|c|c|}
\hline \multicolumn{2}{|c|}{ First Round } & \multicolumn{2}{|c|}{ Second Round } & \multicolumn{2}{|c|}{ Third Round } \\
\hline Themes & Frequency* & Themes & Frequency* & Themes & Frequency* \\
\hline $\begin{array}{l}\text { Experienced heart } \\
\text { palpitation, } \\
\text { sweating of body }\end{array}$ & & $\begin{array}{l}\text { Uttered different } \\
\text { fillers such as ahms, } \\
\text { ehs, anos, etc. }\end{array}$ & & $\begin{array}{l}\text { Popsispeak is a great } \\
\text { way to reduce } \\
\text { anxiety in speaking }\end{array}$ & \\
\hline $\begin{array}{l}\text { parts, and } \\
\text { uncomfortable body } \\
\text { conditions }\end{array}$ & 21 & & 14 & & 24 \\
\hline $\begin{array}{l}\text { Uttered different } \\
\text { fillers such as ahms, } \\
\text { ehs, anos, etc. }\end{array}$ & 25 & $\begin{array}{l}\text { Cannot speak freely } \\
\text { because of } \\
\text { consciousness to } \\
\text { Grammar issues and } \\
\text { pronunciation } \\
\text { lapses. }\end{array}$ & 25 & $\begin{array}{l}\text { Suggested for more } \\
\text { student activities that } \\
\text { would help improve } \\
\text { the speaking } \\
\text { abilities. }\end{array}$ & 23 \\
\hline $\begin{array}{l}\text { Unconfidently faced } \\
\text { the audience } \\
\text { because of several } \\
\text { factors }\end{array}$ & 26 & $\begin{array}{l}\text { Felt a slight } \\
\text { improvement } \\
\text { compared to the } \\
\text { previous } \\
\text { performance }\end{array}$ & 27 & $\begin{array}{l}\text { One semester is not } \\
\text { enough to totally } \\
\text { reduce public } \\
\text { speaking anxiety and } \\
\text { improve the oral } \\
\text { communication } \\
\text { skills. }\end{array}$ & 17 \\
\hline
\end{tabular}

* Multiple Responses

It can be gleaned on the data shown the improvement of the students based on their responses written in their journals. Anxieties are evident on the first and second rounds of the intervention activity. Students admitted several factors that hinder their speaking abilities. On the other hand, it can be inferred that majority of the students liked the Popsispeak activity and clamored for more outcomes-based activities that will help improve their communication skills which are all beneficial in their future endeavors. Many activities were proven by various studies that were beneficial in improving the communication skills and reducing the public speaking anxiety of the learners. A Pronunciation Oral-Communication Manual was tailored to fit to students who would like to elevate their written and spoken English language skills. The said manual includes various drills and dialogues that would surely help the ESL/EFL learners (Handschuh, 1985), It was also proven in Vietnam that visualization techniques such as concept making helped the students elevate their skills in oral communication and other macro skills (Wang \& Liao, 2014). Also, practical and classroom-tested activities helped in enhancing the speaking skills of the students, especially students who are taking businessrelated courses (Grace \& Gilsdorf, 2004).

\section{THE OUTPUT OF THE STUDY}

The output of the study is an intervention package. This includes the mechanics in conducting a Popsispeak activity. All the necessary forms are also included, such as the learning journal of the students, motivational letter, Personal Report of Public Speaking Anxiety test, and the oral communication skills' level test. Instructions on each form are also included. The said 
package is designed for language and non-language teachers who would like to help their students reduce their public speaking anxiety and improve oral communication skills.

\section{CONCLUSIONS AND RECOMMENDATIONS}

Although there is no significant relationship found between the public speaking anxiety and oral communication skills of the students, it was evident that Popsispeak was proven as an effective strategy in reducing the public speaking anxiety and enhancing the oral communication skills of the students. The positive reinforcement and motivation of the teacherresearcher also had a significant impact in addressing the said problem. As to the recommendations, the teacher-researcher conducted a small group discussion to discuss their suggestions for the improvement of this undertaking. It was highlighted that aside from Popsispeak, they are looking forward to more outcomes-based activities that require oral presentations in other courses. They also suggested that the topics in the Popsispeak should not be only limited to words and should not just be applicable in the language courses. Phrases and statements could also be add-ons. Lastly, they recommended that the College should conduct workshops and symposia addressing the communicative skills of the learners.

\section{PERSONAL STATEMENT}

In doing action research, I realized that my role as a language educator is crucial in the lives of my students. In my own simple ways, I should help my students improve their linguistic abilities. I have to continuously innovate and think of creative ways in order for them to acquire lifelong learning skills. This experience made me more committed, dedicated, and passionate in the teaching profession. I will do my best and will always aim for excellence.

\section{ACKNOWLEDGMENT}

The teacher-researcher would like to thank the Camarines Sur Polytechnic Colleges- Research Office for providing the necessary assistance and the opportunity to realize this endeavor.

\section{REFERENCES}

Adult Learning Theory. (1999). Retrieved from https://studylib.net/doc/5892415/adult-learning-theory

Allen, J. (1985, April 30). The Relationship of Communication Anxiety, Avoidance and Competence of NonNative English Speakers in the U.S. Retrieved from https://eric.ed.gov/?id=ED261448

Arafah, B., Yassi, H. \& Imran, N. (2017). Correlation between Level of Anxiety and Public Speaking Performance through Systematic Learning Approach in Foreign Language.

Boath, E., Good, R., Tsaroucha, A., Stewart, T., Pitch, S. \& Boughey, A. J. (2017). Tapping your way to success: using Emotional Freedom Techniques (EFT) to reduce anxiety and improve communication skills in social work students. Social Work Education, 36(6), 715-730.

Carnegie, D. (1937). Public speaking and influencing men in business. Association Press.

Dar, M. F. \& Khan, I. (2014). Oral Communication Apprehension Among Undergraduate Engineering Students in Pakistan. Journal of Education and Social Sciences, 2(2), 144-153. Retrieved from https://geistscience.com/JESS/issue2-14/Article4/JESS1402104.pdf

Del Villar, C. P. (2010). Beginning Filipino students' attributions about oral communication anxiety. Journal Media and Communication Studies, 2(7), 159-169. Retrieved from https://pdfs.semanticscholar.org/9ee1/352b1bbd1b3ac1a57ecad224e3a35b9601e4.pdf

Grace, D. M. \& Gilsdorf, J. W. (2004). Classroom strategies for improving students' oral communication skills. Journal of Accounting Education, 22(2), 165-172.

Harris, S. R., Kemmerling, R. L. \& North, M. M. (2002). Brief virtual reality therapy for public speaking anxiety. Cyberpsychology \& Behavior, 5(6), 543-550.

Human Communication. A Publication of the Pacific and Asian Communication Association. 11(1), 215-226. 
Improving Oral Communication. A Pronunciation Oral-Communication Manual (Book Review). (1985). Education, $106(2), \quad 149 . \quad$ Retrieved from http://search.ebscohost.com/login.aspx?direct=true\&db=a9h\&AN=4717996\&site=ehost-live

Jackson, D. (2014). Business graduate performance in oral communication skills and strategies for improvement. The International Journal of Management Education, 12(1), 22-34.

Jangir, S. K. \& Govinda, R. B. (2017). Reducing Public Speaking Anxiety with Behavior Modification Techniques among School Students: A Study.

Kumar, P., Kaur, J. \& Thakur, N. (2017). Public Speaking Anxiety in Relation to Different Demographic Factors. International Journal of Indian Psychology, 4(4).

Lake, R. (2015). Fear of Public Speaking Statistics and How to Overcome Glossophobia. Retrieved from https://www.creditdonkey.com/fear-of-public-speaking-statistics.html

Mak, B. (2011). An exploration of speaking-in-class anxiety with Chinese ESL learners. ScienceDirect, 39(2), 202-214. doi: https://doi.org/10.1016/j.system.2011.04.002

McCroskey, J. C. (1970). Measures of communication-bound anxiety. Speech Monographs, 37, 269-277.

Nakatani, Y. (2005). The effects of awareness-raising training on oral communication strategy use. The Modern Language Journal, 89(1), 76-91.

Nazir, M., Bashir, S. \& Raja, Z. B. (2014, July). A Study of Second Language Speaking-Anxiety among ESL Intermediate Pakistani Learners. $\quad$ Retrieved http://ijee.org/yahoo_site_admin/assets/docs/22.184151539.pdf

Nkome, M. (2015). Determining reasons for learners' poor communication skills in English in some Lesotho primary schools (Doctoral dissertation).

Overcoming the jitters. (2002). Nursing, 32(1), 68-69. Retrieved from http://search.ebscohost.com/login.aspx?direct=true \&db=a9h\&AN=5842058\&site=ehost-live

Partnership, G. S. (2016, August 25). 21st Century Skills Definition. Retrieved from https://www.edglossary.org/21st-century-skills/

Perveen, K., Hasan, Y. \& Aleemi, A. R. Glossophobia: The Fear Of Public Speaking In Female And Male Students Of University Of Karachi.

Philip, B., Hua, T. K. \& Jandar, W. A. (2019). Exploring Teacher Cognition in Malaysian ESL Classrooms. $3 L$ : The Southeast Asian Journal of English Language Studies, 25(4), 156-178. doi: http://doi.org/10.17576/3L-2019-2504-10

Pribyl, C. B., Keaten, J. \& Sakamoto, M. (2001). The effectiveness of a skills-based program in reducing public speaking anxiety. Japanese Psychological Research, 43(3), 148. Retrieved from http://search.ebscohost.com/login.aspx?direct=true \&db=a9h\&AN=4859579\&site=ehost-live

Raba, A. A. A. (2017). The influence of think-pair-share (TPS) on improving students' oral communication skills in EFL classrooms. Creative Education, 8(01), 12.

Raja, F. (2017). Anxiety Level in Students of Public Speaking: Causes and Remedies. Journal of Education and Educational Development, 4(1), 94-110.

Rastegar, M. \& Gohari, S. S. M. (2016). Communication Strategies, Attitude, and Oral Output of EFL Learners: A Study of Relations. Open Journal of Modern Linguistics, 6(05), 401.

Reitmeier, C. A., Svendsen, L. K. \& Vrchota, D. A. (2004). Improving oral communication skills of students in food science courses. Journal of Food Science Education, 3(2), 15-20.

Sharma, V. (2017, February 17). Importance of Communication Skills for Students. Retrieved November 03, 2018, from http://www.klientsolutech.com/importance-of-communication-skills-for-students/

Şimon, S. (2014). Enhancing the English Oral Communication Skills of the 1st Year Students of the Bachelor's Degree Program "Communication and Public Relations". Procedia-Social and Behavioral Sciences, 116, 2481-2484.

Suwanarak, K. (2019). Use of Learning Strategies and their Effects on English Language Learning of Thai Adult Learners. 3L: The Southeast Asian Journal of English Language Studies, 25(4), 99-120. doi: http://doi.org/10.17576/3L-2019-2504-07

Wang, Y. H. \& Liao, H. C. (2014). Promoting English oral communication and higher-order thinking in Taiwanese ESL students through the use of knowledge visualization techniques. Perceptual and motor skills, 118(3), 691-708.

What are $21^{\text {st }}$ century skills? (2016, October 03). Retrieved from https://k12.thoughtfullearning.com/FAQ/whatare-21st-century-skills

Young, D. J. (1990). An investigation of students' perspectives on anxiety and speaking. Foreign Language Annals, 23(6), 539-553. 


\section{APPENDIX A}

\section{ORAL COMMUNICATION SKILLS LEVEL TEST}

Name:

Date:

Year/Course:

Organization: (10 points)

- Your speech has a clear beginning, middle, and end

- The point you are speaking to and/or the point you wish to make is clear 13

- You close clearly, summarizing your point if necessary

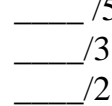

Content: (10 points)

- You support your point with at least THREE distinct details

- Your details show a sensitivity to or awareness of your audience

15

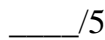

$/ 10$

- You demonstrate proficiency with: Vocal Variety, Vocal Projection and Volume, Speaking Rate, limited Verbal Clutter, Limited Verbal Fillers and Dysfluencies, Pronunciation, Articulation, Strategic Use of Language, Eye Contact, Posture, Gestures and Movement, Appropriate Grammar

TOTAL POINTS:

Level:

25-30 Advanced

19-24 Proficient

13-18 Approaching Proficiency

7-12 Developing

0-6 Beginning 


\section{APPENDIX B}

\section{PERSONAL REPORT OF PUBLIC SPEAKING ANXIETY}

Name: Date:

Yr/Course:

Score:

PSA Level: ( ) Low ( ) Moderate ( ) High

Directions: Below are 34 statements that people sometimes make about themselves. Please indicate whether or not you believe each statement applies to you by marking whether you:

Strongly Disagree $=1 ;$ Disagree $=2 ;$ Neutral $=3 ;$ Agree $=4 ;$ Strongly Agree $=5$.

1. While preparing for giving a speech, I feel tense and nervous.

2. I feel tense when I see the words "speech" and "public speech" on a course outline when studying.

3. My thoughts become confused and jumbled when I am giving a speech.

4. Right after giving a speech I feel that I have had a pleasant experience.

5. I get anxious when I think about a speech coming up.

6. I have no fear of giving a speech.

7. Although I am nervous just before starting a speech, I soon settle down after starting and feel calm and comfortable.

8. I look forward to giving a speech.

9. When the instructor announces a speaking assignment in class, I can feel myself getting tense.

10. My hands tremble when I am giving a speech.

11. I feel relaxed while giving a speech.

12. I enjoy preparing for a speech.

13. I am in constant fear of forgetting what I prepared to say.

14. I get anxious if someone asks me something about my topic that I don't know.

15. I face the prospect of giving a speech with confidence.

16. I feel that I am in complete possession of myself while giving a speech.

17. My mind is clear when giving a speech.

18. I do not dread giving a speech.

19. I perspire just before starting a speech.

20. My heart beats very fast just as I start a speech.

21. I experience considerable anxiety while sitting in the room just before my speech starts.

22. Certain parts of my body feel very tense and rigid while giving a speech.

23. Realizing that only a little time remains in a speech makes me very tense and anxious.

24. While giving a speech, I know I can control my feelings of tension and stress.

25. I breathe faster just before starting a speech.

26. I feel comfortable and relaxed in the hour or so just before giving a speech.

27. I do poorer on speeches because I am anxious.

28. I feel anxious when the teacher announces the date of a speaking assignment.

29. When I make a mistake while giving a speech, I find it hard to concentrate on the parts that follow.

30. During an important speech I experience a feeling of helplessness building up inside me.

31. I have trouble falling asleep the night before a speech.

32.My heart beats very fast while I present a speech.

33. I feel anxious while waiting to give my speech.

34. While giving a speech, I get so nervous I forget facts I really know.

This standardized test devised by McCroskey will determine the anxiety level of the students in public speaking.

Here's how:

Scoring: To determine your score on the PRPSA, complete the following steps:

Step 1. Add scores for items 1, 2, 3, 5, 9, 10, 13, 14, 19, 20, 21, 22, 23, 25, 27, 28, 29, 30, 31, 32, 33, and 34

Step 2. Add the scores for items 4, 6, 7, 8, 11, 12, 15, 16, 17, 18, 24, and 26

Step 3. Complete the following formula:

PRPSA $=72$ - Total from Step $2+$ Total from Step 1

Your score should be between 34 and 170. If your score is below 34 or above 170, you have made a mistake in computing the score.

High $=>131$

Low $=<98$

Moderate $=98-131$

Mean $=114.6 ; \mathrm{SD}=17.2$ 


\section{APPENDIX C}

\section{REFLECTIVE JOURNAL}

Name:

PopsiSpeak no.

Date:

\begin{tabular}{|l|c|c|}
\hline What happened? & $\begin{array}{c}\text { How do I feel } \\
\text { about it? }\end{array}$ & What did I learn? \\
\hline & & \\
& & \\
& & \\
\hline
\end{tabular}

\section{APPENDIX D}

MOTIVATION LETTER TEMPLATE TO STUDENTS

Dearest

You did a great job! :) :-; :-

You did it!

Very truly yours,

Dearest

You did a great job! $(;) ;$

You did it!

Very truly yours, 